\title{
Influences of forest type and habitat structure on bird assemblagesof oak (Quercus spp.) and pine (Pinus spp.) stands in southwesternTurkey
}

\author{
Adam Bergner, Mustafa Avci, Hasan Eryigit, Nicklas Jansson, \\ Mats Niklasson, Lars Westerberg and Per Milberg
}

\section{Linköping University Post Print}

\section{Tweet}

N.B.: When citing this work, cite the original article.

Original Publication:

Adam Bergner, Mustafa Avci, Hasan Eryigit, Nicklas Jansson, Mats Niklasson, Lars Westerberg and Per Milberg, Influences of forest type and habitat structure on bird assemblagesof oak (Quercus spp.) and pine (Pinus spp.) stands in southwesternTurkey, 2015, Forest Ecology and Management, (336), , 137-147.

http://dx.doi.org/10.1016/j.foreco.2014.10.025

Copyright: Elsevier http://www.elsevier.com/

Postprint available at: Linköping University Electronic Press http://urn.kb.se/resolve?urn=urn:nbn:se:liu:diva-111925 


\title{
Influences of forest type and habitat structure on bird assemblages of oak (Quercus spp.) and pine (Pinus spp.) stands in southwestern Turkey
}

\author{
Adam Bergner ${ }^{\mathrm{a}}$, Mustafa Avcı ${ }^{\mathrm{b}}$, Hasan Eryiğgit ${ }^{\mathrm{c}}$, Nicklas Jansson ${ }^{\mathrm{a}}$, Mats Niklasson ${ }^{\mathrm{d}}$, \\ Lars Westerberg $^{\mathrm{a}}$ and Per Milberg ${ }^{\mathrm{a}}$ \\ aFM Biology, Division of Ecology, Linköping University, Linköping, Sweden \\ ${ }^{\mathbf{b}}$ Faculty of Forestry, Süleyman Demirel University, Isparta, Turkey \\ 'Isparta Province Forest District Directorate, Isparta, Turkey \\ ${ }^{\mathrm{d}}$ Southern Swedish Forest Research Centre, SLU, Alnarp, Sweden \\ Correspondence: Per Milberg \\ Email: permi@ifm.liu.se
}

\begin{abstract}
The Mediterranean basin exhibits a multitude of forest habitats affected by former and current exploitation and management. Recent afforestation programs have resulted in an increase in the proportion of coniferous trees, while oak stands, formerly utilized for coppicing and grazing, are abandoned or converted into coniferous plantations. The loss of oak stands might negatively affect birds dependent upon broadleaved forests. Studies confirming or rejecting that statement are scarce, particularly in the eastern part of the region. Using a study area in southwestern Turkey we applied a guild-based approach to investigate how pine and oak stands across a chronosequence differ in their capacity to support forest bird assemblages. Variables describing the vegetation were sampled to characterize the stands and relate bird assemblages to stand structure. Bird abundance and species richness was positively associated with age for both stand types. Richness and diversity was highest in oak stands, while there were no differences in bird abundance between the two forest types. Pine stands supported a different bird species composition compared to oak stands of the same age. Stand age and structure, rather than forest type, held the highest explanatory powers for bird assembly structure. Primary cavity-nesters and ground-nesters were more abundant in oak stands, possibly reflecting differences in stand structure and resource distribution. To support these birds with suitable habitats, oaks stands need conservation. Management practices in pine stands should strive for increasing the amount of old trees and retain vegetation in the understory to benefit breeding birds.
\end{abstract}

Keywords: Birds, Forestry, Guilds, Management, Oak, Pine

\section{Introduction}

Ecosystems of the Mediterranean basin have a long history of man-induced disturbance and management. For thousands of years, native forests were overexploited for the multiple goods and services they provided, resulting in degradation of many forests in the region (FAO, 2013). Fires, agricultural expansion and intensive grazing by domestic animals also contributed to the loss of vegetation and constrained the emergence of new vegetation (Thirgood, 1981), turning many areas into degraded land heaviliy exposed to soil erosion (Blondel and Aronson, 1999). Since the 1950s, 
afforestation practices have been extensively implemented. Native or exotic pines (Pinus spp.) have been planted over vast areas to re-establish trees on deforested land and promote future recovery of native secondary vegetation, such as oak (Quercus spp.) forests (Pausas et al., 2004; Maestre and Cortina, 2004).

With more than 20 species occuring in the Mediterranean basin (Scarascia-Mugnozza et al., 2000), oaks comprise a significant amount of the broadleaved trees. Many oak stands have been traditionally utilized by rural communities, either as coppices providing timber and wood fuel, or as pastures (e.g. Robles et al. 2007). Due to changes in socio-economical conditions, cessations of these practises have become more frequent recently (Debussche et al., 2001; Ciancio et al., 2006, Hartel et al. 2014), leaving coppices abandoned (Barbéro et al., 1990) or converted into monospecific plantations managed for timber production (Fabbio et al., 2003). Traditionally managed stands often harbour a high biodiversity (Bergmeier et al., 2010), and the loss and replacement of these habitats in favor for conventionally managed forestry plantations is believed to have negative implications for many forest organisms (e.g. Spitzer et al., 2008; Hartel et al. 2014), including highly specialized species (e.g. Robles et al., 2007). The rapid transformation of the forest landscape is of particular concern for the conservation of biodiversity associated with traditionally managed stands in the species-rich Mediterranean basin.

Managing forests to enhance their capacity of supporting biodiversity is a fundamental and desirable aspect of sustainable forestry. Responses of biodiversity to different management regimes in forest ecosystems have mainly been studied using suitable indicator species, but their reliability remains uncertain (Lindenmayer et al., 2000). Birds play a vital role in forest ecosystems and are considered good biodiversity indicators (Şekercioğlu, 2006). Consequently, they have been thoroughly used in studies comparing species richness and composition between natural forests and plantations (Stephens and Wagner, 2007). Their potential as indicators of forest stands with different history and management, however, has been less explored. Within a forest landscape, the structure of bird assemblages can be explained by factors determining forest bird distributions across multiple spatial scales (Gil-Tena et al., 2009; Özkan et al., 2013). Limiting factors at stand-level are food resource availability (e.g. Robles et al. 2007) and access to suitable nest sites (Newton, 1998; Robles et al. 2012), factors partly determined by stand structural complexity. This implies that stands of higher heterogeneity create a larger niche-space, hence sustaining a higher avian diversity (Tews et al., 2004). Stand characteristics such as age and dominant tree species are known to influence the abundance and distribution of forest birds. Several studies have found positive associations between stand age and bird species richness in both natural and semi-natural forests (e.g. Gil-Tena et al., 2007; Etterson et al., 2007; Nikolov, 2009) and plantations (Lindenmayer and Hobbs, 2004). Managed stands of broadleaved and coniferous trees located in the same region have been found to support different assemblages of bird species (e.g. Díaz, 2006; Sweeney et al., 2010a), potentially reflecting differences in resource distribution. To what degree any of these factors explain differences in bird richness and species composition is poorly studied, particularly in the eastern Mediterranean basin, but constitutes a key aspect for successful management of forest stands.

The Taurus Mountains of southwestern Turkey are characterized by a high frequency of natural pine forests at high altitudes, gradually shifting towards forestry plantations at lower altitudes. Oak stands also differ in their origin, ranging from unmanaged natural stands, usually at higher altitudes, to artificially regenerated stands formerly utilized for coppicing and pollarding. The large variation in management gives rise to forest stands with a varying array of traits and associated biodiversity. In a country where the state and other public entities own more than $99 \%$ of the forests (Atmiş et al., 2007), recent afforestation practices in Turkey have followed those of other parts of the Mediterranean basin, through the establishment of coniferous plantations (Sama et al., 2011) and conversion of native 
forests into coniferous plantations (Kaya and Raynal, 2001; Öztürk et al., 2010). Biodiversity conservation, as a part of sustainable forestry, has so far had a low priority in forest planning and management in Turkey (Çolak and Rotherham, 2006; Başkent et al., 2008). Addressing this issue require studies on the effects of different biodiversity indicators in stands of different attributes and management.

Up to this date, comparisons of species richness and composition of forest birds inhabiting oak and pine stands are lacking from southwestern Turkey. Exploratory and comparative studies are therefore needed to increase the knowledge on the effects of different management regimes. To cover a wide array of forest attributes, we used a chronosequence ranging almost 185 years. Using a guildbased approach, we separated the effects of tree species (forest type), stand structure and stand age on richness, diversity and biomass (metabolic weight) of breeding birds. The aims were to identify bird assemblages of oak and pine stands, to discuss about the factors explaining any potential differences observed and present suggestions of improved forestry management to promote breeding forest birds, and especially so in pine stands, that dominate forestry in the study area.

\section{Methods}

\section{Study area and selection of study sites}

Field work was conducted during May and June 2013 in Isparta province, southwestern Anatolia, Turkey (Figure 1). The area is situated near the transition between the Taurus Mountains and the inner Anatolian plateau and has a typical continental climate, i.e. hot and dry summers and cold and rainy winters. Mean annual precipitation is $508 \mathrm{~mm}$ and the mean annual temperature $12.2{ }^{\circ} \mathrm{C}$, with July and August being the warmest months (Turkish General Directorate of State Meteorology, 2014). The province contains mountainous coniferous forests (mainly Turkish pine (Pinus brutia), Crimean pine (P. nigra ssp. pallasiana) and Taurus cedar (Cedrus libani ssp. stenocoma)), vast cultivated plain lands and a few large freshwater lakes. Apart from extensive areas of maquis vegetation, some mountain slopes and valleys are covered by scattered oak forest stands, both abandoned coppices and wood pastures currently grazed by domestic goats.

Suitable study sites were identified in close cooperation with the Province Forest District Directorate in Isparta using maps and field visits. The sites differed in their history and management, ranging from conventionally managed pine plantations through abandoned oak coppices to grazed pine and oak forests of higher naturalness, why they henceforth will be referred to as stands. Pine stands comprised one of the three species Pinus brutia, P. nigra ssp. pallasiana or P. sylvestris and oak stands one or a few of the species Quercus cerris, $Q$. infectoria, $Q$. libani, $Q$. vulcanica, $Q$. ithaburensis and $Q$. coccifera. A chronosequence of 185 years was used, where the surveyed stands were evenly distributed along the age gradient. A final selection was done based on logistic considerations, ending up in 15 stands of oak and 17 stands of pine. The oak stands were located at altitudes ranging from 1004 to $1524 \mathrm{~m}$ and the pine stands located at altitudes ranging from 856 to $1376 \mathrm{~m}$.

\section{Bird surveys}

Birds were counted using point taxation (see Bibby et al., 2000) from randomly distributed points in interior parts ( $>80 \mathrm{~m}$ from edges) of oak and pine stands. Each stand was assigned four points located at least $120 \mathrm{~m}$ apart to avoid counting any bird more than once. The points were located

in field using a GPS (Garmin GPSMAP 62st). Surveying was practiced using distance sampling within 
a fixed radius of $50 \mathrm{~m}$, divided into ten meter wide distance bands. The positions of all resident songbirds, woodpeckers and pigeons were registered on standardized radii maps using aural or direct observation during periods of 10 minutes. Distances were mostly estimated, but a $50 \mathrm{~m}$ measuring tape was sometimes used as a reference. For logistic reasons, the stands were visited according to a rotational schedule of two three-week periods. During the first period, May 5-30, half of the forest stands were visited between 9-12 AM and the other half between 3-6 PM. During the second period, June 1-29, early visits were allocated to the stands previously visited late, and vice versa. The two time periods were chosen mainly because of logistic constraints and staff limitation. Temporal separation of the two visits was done primarily in order to adjust for seasonal and diurnal effects of time, and increase the chance of detecting as many of the resident bird species as possible. Observations were conducted on days without persistent rain or strong winds ( $<4$ on the Beaufort scale). All point observations were carried out by one person $(\mathrm{AB})$, therefore limiting the effect of observer bias. Based on the number of territorial birds registered within the distance bands, an assessment of the number of established territories for each species was made. There was an exception for Long-tailed Tit (Aegithalos caudatus), a species frequently occurring in flocks (e.g. Hatchwell et al., 2001), where one group of individuals was assumed equal to one territory. Newly fledged birds and birds only seen in flight were excluded from the analyses since their residency in the study area was uncertain. Additionally, non-resident bird species passing during migration, such as Willow Warbler (Phylloscopus trochilus) and Blackcap (Sylvia atricapilla), were not documented. For each taxation point, the final amount of territories was based on the highest number of individuals for each species noted during any of the two visits. Reference literature for species identification included Svensson et al., (2009) and Gündoğdu et al., (2009).

\section{Sampling of environmental variables}

\section{Stand structure}

In each forest patch the following vegetation data were sampled around two of the four points. (1) tree trunk density per $100 \mathrm{~m}^{2}$ assessed by counting the number of trees ( $>2 \mathrm{~m}$ height) within one meter on each side of two $50 \mathrm{~m}$ transects. Each transect extended in a randomly chosen compass direction (N, S, E or W) from the center of the observation points. (2) Tree trunk circumferences measured on a total of six randomly selected trees along each transect, yielding a total of 24 trees per forest stand. In cases when transects did not hold a sufficient amount of trees, this point was excluded and sampling was made on trees around another, randomly chosen, observation point. (3) The structure of understory vegetation was characterized for two types of plants: grass, herbs and nonlignified vascular plants (henceforth denoted grass and herb cover), and shrubs and low trees $\leq 2 \mathrm{~m}$ of height (henceforth denoted shrub cover). Estimations were based on frame areal coverage (in percent) calculated from high-resolution photos taken using a Canon EOS 550D. Photos were taken at $70 \mathrm{~cm}$ height perpendicular to the ground in all four main compass directions from three out of four observation points, yielding a total of 12 photos per forest stand. Environmental and vegetation data used for further analyses was based upon mean values of all measurements registered at taxation points within each stand.

\section{Stand age}

Stand age determined by means of dendrology was based on the mean value of tree ring cores extracted at breast height (approximately $130 \mathrm{~cm}$ above ground) in each forest stand using a Swedish increment borer (Ø5 mm). Trees selected for coring exhibited circumferences near the average value based on data from the survey of tree trunk circumferences. Most pine stands and the younger oak stands (former coppices) exhibited a rather uniform stand structure and were therefore represented 
with cores from 2-3 trees per patch. Test cores revealed that the trees growing in these stands showed little intra-site age differences. In older, more heterogeneously structured stands four cores were sampled. In the oldest oak stands, the age recorded was based on the age of the oldest non-hollow tree possible to core.

The cores were glued to wooden lists and sanded with subsequently finer grades of sandpaper, the finest grade was 600 grit. The cores were age-determined under a dissecting microscope. In cases where the cores were too short to reach the center of the trunk, approximate age was calculated by extrapolating the average ring-width of the three inner-most rings to the missing radii length (calculated from core length and the tree trunk circumference).

\section{Statistics}

\section{Bird density calculations}

Since detectability of birds decreases with the distance from the observer (Thomas et al., 2002), and presumably differs between species (Boulinier et al., 1998) and forest types of different structure (Schieck, 1997), the observed numbers were recalculated based on estimated detectability. Using the software DISTANCE (see Thomas et al., 2010) the sampled data was fitted to a half-normal cosine model describing the relationship between distance and detectability. Analyses based on multiplecovariate distance sampling (MCDS) were carried out to test for effects of habitat factors potentially influencing the detection function (see Marques et al., 2007). Detectability differed between the two forest types, but adding shrub-coverage and tree trunk density as covariates did not explain the differences, i.e. did not generate lower AIC-values. By using forest type as a covariate, mean detection rates for oak and pine stands were calculated. The more abundant bird species possessed data enough for reasonable calculations of detectability, thus serving as models to scarce species of similar behavior and assumed detectability rates.

\section{Bird guild classification}

The recorded bird species were classified into guilds based on their nest-site preferences, using information obtained from Cramp et al., (1980-1994). Species sharing similar types of nest-sites were grouped to create six well-defined guilds (Table 1). In all cases, the species were grouped according to their most frequently used nest-site selection. Mean territory densities per guild for each forest stand were used for further analyses.

\section{Metabolic weight}

Data on body mass for each bird species recorded in the study was extracted from Cramp et al., (1980-1994). For each species, the sum of the weight of one male and one female was multiplied by the number of territories at a site. The site-wise sum of all species then represents the estimated bird biomass (denoted $\mathrm{W}$ ). These values were used to calculate total metabolic weights (here denoted MW) of bird assemblages for each forest stand according to Banavar et al. (2010) using the formula:

$$
\mathrm{MW}=\mathrm{W}^{(3 / 4)}
$$

\section{Generalized linear model (GLZ)}

The relationships between bird species richness, territory density and metabolic weights were tested against corresponding stand age of oak and pine stands using GLZ (normal distribution, gamma $\log$ link function). The responsive effects of guild density for each forest stand were tested against 
constituent habitat parameters using GLZs based upon normalized data. Statistical analyses were performed using the softwares SPSS Statistics 22 and Statistica 12.

\section{Multivariate analyses}

The associations between species and stand parameters were displayed in a redundancy analysis (RDA) using the software CANOCO 5.0 (ter Braak and Šmilauer, 2012). Due to relatively low betadiversity, multivariate methods based on linear assumptions were used. P-values were generated by running a conservative Monte Carlo test (9999 permutations) and investigate the effects of forest type on the structure of bird assemblages. In the analyses, forest type and variables describing stand structure were tested separately to identify the factor accounting for the highest explanatory power. Furthermore, variation partitioning analysis was conducted on bird guild data, to assess the relative explanatory importance of variables.

A separate RDA was conducting using only data from pine stands, and with the purpose to identify possible strategies that could promote breeding forest birds in what is likely to remain the main habitat subjected to forestry in the study area.

\section{Results}

\section{Stand structure}

Oak stands differed from pine stands by having a higher cover of grass and herbs (Table 2). In general, the surveyed oak stands were located at somewhat higher altitudes and had smaller tree trunk circumferences than pine (Table 2), mainly resulting from differences in growth rates between oak and pine. The factor stand age was positively related to with mean tree trunk circumference (Pearson correlation $\mathrm{R}=0.707, \mathrm{p}<0.001)$ and negatively correlated with tree trunk density $(\mathrm{R}=-0.592, \mathrm{p}<0.001)$. Total shrub cover and cover of grass and herbs were negatively correlated $(R=-0.520, p=0.002)$.

\section{Bird species richness and diversity}

A total of 40 bird species were registered in the 32 surveyed stands (Table 1, Appendix). The number of territories was recalculated into integers based on out-put data obtained from DISTANCE calculations, thus yielding a total of 1119 territories of 35 species in the oak stands $(n=15)$, and 1078 territories of 30 species in the pine stands $(n=17)$. Forest stands of oak supported different bird species assemblages than pine stands. In total, 25 species were found in both forest types, five species only in pine stands, and ten species only in oak stands (Table 1).

Total species richness was on average higher in the oak stands (Table 3), and increased with increasing age for both pine and oak stands (GLZ; $n=32 ; p=0.001$ ) (Figure 2). With age, however, species richness seemed to level off (Figure 2). Shannon-Wiener diversity index $\left(\mathrm{H}^{\prime}\right)$ was on average higher in oak than in pine stands (Table 3). Beta $(\beta)$ diversity in the data, i.e. the turn-over of species from one sample to the next (true beta diversity), was similar for the two forest types (1.33 and 1.35 for oak and pine, respectively); hence, there was no indication of a difference between the two forest types in how species were distributed among stands.

The total density of forest bird territories was lowest in young stands of both pine and oak, and increased with increasing age of forest stands (GLZ; $n=32 ; \mathrm{p}<0.001$ ). There were no differences in total territory density between stands of oak and pine (Table 3 ). 
Total metabolic weight of bird assemblages increased with increasing age of forest stands (GLZ; $n=32 ; p=0.044$ ), but did not differ between stands of oak and pine (Table 3).

\section{Associations with forest type}

Adjusted for effects of stand structure, the factor forest type (oak or pine) explained the observed differences in abundance for primary-cavity nesters and ground-nesters. Both guilds had significantly higher territory densities in oak stands than in pine stands (Figure 3). For other guilds, there was no effect of forest type (Figure 3).

\section{Associations with stand age}

GLZs were used to investigate the associations between the densities of individual bird-guilds and stand age, regardless of forest type. Although no guilds exhibited significant responses to stand age, secondary cavity-nesters and low-canopy nesters showed clear positive associations with stand age, while shrub-nesters exhibited a negative association with stand age (Figure 4).

\section{Associations with stand structure}

The variation partitioning analysis of bird guild data showed that stand structure uniquely explained $21 \%$ of the variation in species composition. In contrast, forest type alone explained only $2 \%$, leaving $10 \%$ for their combined explanatory power.

The RDA revealed varying associations of species with environmental variables (Figure 5a). Stand age was an important explanatory factor for high- and low-canopy nesters and secondary cavitynesters (Figure 5b). Primary cavity-nesters were associated with an increase in forest floor cover of grass and herbs (Figure $5 b$ ). Shrub-nesting species were associated with higher shrub cover and tree trunk density while ground-nesters were well-associated with the forest type oak (Figure 5b). Among the environmental variables, forest age accounted for the highest explanatory power at $19.1 \%$ of the total variation in guild abundance data (pseudo- $\mathrm{F}=7.1, \mathrm{p}=0.0012$ ).

\section{Bird-habitat associations in pine stands}

The main guild-vegetation associations for pine were analyzed separately to identify possible strategies that could promote breeding forest birds (Figure 6). The strongest associations of bird guilds/stand characteristics were for high-canopy nesters/stand age, shrub-nesters/tree trunk density and ground-nesters/grass and herb cover, while the other groups had short arrows, or were not so clearly associated with the stand variables.

\section{Discussion}

The assessment of forest attributes as determinants of biodiversity and species assembly structure is important for suitable management measures and conservation targets in forest stands. Using forest birds as indicators, this study presents the first results of an assessment of biological values in broadleaved and coniferous stands in southwestern Turkey. Compared to pine, oak stands supported higher bird species richness and diversity (Shannon $\mathrm{H}^{\prime}$ ), and a larger number of unique species. As oak and pine stands had similar beta diversity (i.e. the same amount of species turnover between stands), the observed differences in Shannon H' diversity is not due to oak and pine differing in inter-site variation. 
Despite distinct differences in species richness and diversity, the two forest types supported similar numbers of bird territories per hectare. This implies that the lack of certain broadleaved species in pine stands is compensated by a net gain of species preferring coniferous trees, and vice versa. This is not an unexpected finding, given results from previous European studies. Most of these, however, compared native broadleaved forests and coniferous stands exclusively managed as plantations, where the differences in bird abundance might be more pronounced. Even so, no clear differences in bird abundance were found between managed stands of coniferous and managed broadleaved trees in Spain (Díaz, 2006), Great Britain (Donald et al., 1998) or France (Archaux and Bakkaus, 2007). Despite its effects on bird species composition, the factor forest type alone had a rather low explanatory power, as showed in a variation partitioning analysis, pointing to stand age and stand structure as the most important explanatory variables. This is in line with the results of Wilson et al. (2006) pointing to the growth stage of forests, rather than dominant tree species, as the most explanatory variable determining bird assembly structure.

Oak and pine stands generally supported the fewest species at young ages, and gained more species as stand age increased. This is consistent with results from many studies conducted in various forest ecosystems around the world, for example boreal pine in Canada (Venier \& Pearce, 2005), Mediterranean oak and pine in Spain (Gil-Tena et al., 2007) and eucalypt in Tasmania (Hingston and Grove, 2010). Even so, no bird guild in the present study was significantly correlated with stand age (only marginally so; Figure 4). This is a bit surprising, given how increasing age and successional development in forest habitats affect stand structure, vegetation composition and the emergence of key structures. With increasing age, complex structures like cavities and deadwood develop (Regnery et al., 2013), creating stand heterogeneity that presumably supports a higher bird species richness (Tews et al., 2004). Most forests in the study region, however, lack a few or many of these characteristics, mainly due to former and current management. Both oak and pine stands are commonly monospecific and even-aged, lacking substantial understory growth due to grazing and removal of shrubs. Lying deadwood appears to be a rare element in most forests as fallen branches and twigs are commonly collected by rural communities to be used as fire-wood.

A substantial change in bird assembly structure followed stand development for both oak and pine, resulting in the disappearance of species typical of the pre-thicket stage and the colonization of those typical of forests with taller vegetation, as previously stated by Sweeney et al., (2010b). Evaluated for groups of species the results were less clear. The guild high-canopy nesters, including species typical of more developed forests, did not show any clear relationship with stand age (adjusted for forest type, Figure 4). The reason for that may be due to differential response from species to forest maturation, resulting in an assemblage less functional as a guild. Along the chronosequence, some species occurred in young and old stands - that were semi-open - while they were missing in the dense stands of intermediate age. This supports the idea that age alone, although being important for the structural aspects of forest habitats, does not explain the presence of some species, but rather reflects the abundance of joint stand attributes. Hence, management of production forests for bird conservation might specifically take forest structure into account as this seems most decisive for most feeding guilds of birds.

Forest stands of oak and pine in Isparta province supported different set-ups of bird species assemblages. At the level of guilds, two groups were more abundant in oak stands than in pine stands of similar age: primary cavity-nesters and ground-nesters. The primary cavity-nesters, represented by five species of woodpeckers, were almost exclusively found in oak stands. Many woodpecker species specialize in their use of the forest resources and are dependent upon large or deciduous trees for foraging and nesting (Mikusiński et al., 2001; Robles et al., 2007; Ciudad et al., 2009; Robles \& Ciudad, 2012; Touihri et al., 2014). One of the observed species, the Middle-spotted Woodpecker 
(Dendrocopos medius), is highly associated with mature oak stands in the Mediterranean (Robles et al., 2007) and are often considered a suitable indicator of valuable broadleaved forests (Pasinelli, 2000; Roberge \& Angelstam, 2006). Specialized birds like woodpeckers may rely on other stand structures of oak forests than examined in this paper, thus they do not necessarily follow the general patterns for bird assemblages in forest stands. Due to their high affinity for broadleaved forests, the explanatory factor forest type may apply to woodpeckers more strongly than to other guilds.

Woodpeckers create cavities used by other avian species (Martin and Eadie, 1999), but not necessarily in the current study system, as we found that the density of secondary cavity-nesters was higher in pine than in oak, while the latter has most primary cavity-nesters (cf. Cockle et al, 2011). The reason for this is not entirely clear, but could be due to existing cavities found on other substrates than wood, for example in the ground or as rock crevices. If access to suitable nest sites is not a limiting factor, the broad food preferences found in many species of parids might also explain the observed differences. Secondary cavity-nesters were highly associated with the explanatory factor stand age, indicating that they are dependent upon developed forests where naturally generated cavities are more common. This is in line with the results of Robles et al. (2011) that found higher densities of nest cavities and secondary cavity-nesters in old oak forests.

When suggesting habitat management in forest stands, knowledge on the traits of particular birds are needed. The warbler genus Sylvia has been proposed as one of few groups of birds that originated in the maquis-dominated vegetation of the Mediterranean basin (Blondel and Farré, 1988). These birds benefit from open shrubby habitats and are known to decrease in numbers as forests develop and vegetation height increases. In forest stands of Isparta province, the guild shrub-nesters, although containing few species, were found to be well associated with total shrub cover in patches of both pine and oak. Managed coniferous stands, particularly younger shrubby pine plantations, possibly resembling maquis, were frequently utilized as breeding habitats. Conventional management involves the removal of a substantial part of the understory in order to prevent establishment and spread of wildfires. These practices might have negative consequences for birds dependent upon shrubs for breeding and foraging. Camprodon and Brotons (2006) showed that it was possible to keep breeding Sylvia-species in managed forests as long as sufficient shrub-layer was retained in the understory. When shrub-vegetation was removed, these species, however, disappeared from the forests. These structures are often highlighted as important considering in forest management to enhance overall species richness (Lopez and Moro, 1997; Heyman, 2010). In addition, the present study also highlighted the importance of grass and vascular plants in the understory to benefit birds nesting on the ground. One example is the Eastern Bonelli's Warbler (Phylloscopus orientalis), one of the most common passerines in oak stands in the studied area (2.7 territories ha $^{-1}$, compared with 0.33 in pine stands), particularly in abandoned coppices or dense woodlands moderately grazed by domestic animals. The species places and conceals its nests in grass tussocks or in the vicinity of shrubs. Lack of these features in managed pine stands may be one explanation for why the species is rare in most pine stands.

An important factor limiting population density is the number of individuals that an area can support (Tellería and Carrascal, 1994), implying that resource distribution can explain differences in bird assemblages between stands. Calculated metabolic weights of bird assemblages in oak and pine stands in Isparta province demonstrated positive associations with stand age for both forest types. This relationship did not differ between stands of oak and pine, indicating that the availability and distribution of total food resources is fairly equal. Managed plantations, especially those comprising exotic tree species, are usually considered less hospitable for most forest organisms (Hartley, 2002). Sweeney et al., (2010a) suggested that the differences in bird species richness demonstrated between native broadleaved forests and exotic conifer plantations could be explained by a lower carrying 
capacity of conifer plantations. In the case of southwestern Turkey, where both pine and oak stands are native in origin but have been influenced by different management regimes, these differences - if at all present - do not seem to be prominent. The apparent differences in stand structure and plant properties might have important implications regarding food resource availability for breeding birds. Although birds move while foraging, resource distribution at habitat level could be an important factor limiting the capacity of a stand to support various species or guilds. In a study comparing the richness of invertebrates associated with different tree species in Great Britain, Kennedy and Southwood (1984) found an overall higher diversity and abundance of invertebrates in broadleaved stands than in coniferous ones. Openness in forest canopy might affect the number of invertebrates present in a forest stand. In studies of oak stands of central Europe, Horak et al., (2014) found a higher abundance and diversity of invertebrate taxa in open and semi-open habitats than in forests with higher degrees of canopy closure. On the other hand, Pereira et al., (2014) showed that insectivorous warblers were more abundant in dense oak stands with a more extensive cover of understory vegetation. Insectivorous, ground-nesting passerines, such as the Eastern Bonelli's Warbler, apart from being constrained by lack of suitable nest sites, might also face a lack of food resources, which limits its distribution in pine stands.

This study evaluated the effects of environmental variables on bird assemblages at the scale of forest stands. Many studies performed lately have expanded this to include environmental variables at larger spatial scales, hypothesizing that the bird assembly structure of a particular forest stand is determined by factors in the surrounding matrix (e.g. Gil-Tena et al., 2009; Özkan et al., 2013). Examples of these effects have been demonstrated in studies where managed pine plantations in proximity to native forests supported higher bird species richness than pine plantations lacking native forests in the matrix (Barbaro et al., 2005; Luck and Korodaj, 2008). Stand size and connectivity to surrounding forest stands are known to be important determinants of forest bird assemblages in both native forests and plantations (e.g. van Dorp and Opdam, 1987; Enoksson et al., 1995; Díaz et al., 1998), implying that smaller isolated patches of forests may have a lower species richness than larger patches of the same habitat. In a Spanish study, Santos et al., (2002) found that native stands of holm oak $(Q$. ilex) had to be of significantly larger size than similar stands located in central Europe in order to support equal numbers of bird territories and species. This was proposed to reflect the generally less favorable habitats for birds created from anthropogenic disturbances causing fragmentation and deterioration. The historical situation in southwestern Turkey corresponds to that of the Iberian Peninsula, with long-lasting human exploitation of the forest landscape. Within the Turkish province studied in this paper, stands of particularly old oaks are few, often small and fragmentally distributed in landscapes with arable land and managed coniferous plantations in the matrix. Hence, it is possible that the small explanatory effect of forest type in the current study might, in fact, partly be due to oak stands today having a depauperate bird fauna. With this information at hand, oak stands need to be of substantial size to maintain viable populations of vulnerable bird species. Although not yet studied, the current situation for oak stands in southwestern Turkey indicates that these habitats may provide limited space for species dependent upon large continuous areas of broadleaved forests. For successful conservation and management of oak stands, planning at larger spatial scales may therefore need to be considered.

\section{Conclusions}

Three conclusions can be drawn regarding the relative importance of stand age, forest type and stand structure. First, not unexpectedly, metabolic weight of guilds, richness, diversity and species composition were all clearly affected by age. Second, forest type - i.e. oak vs pine - had a surprisingly modest direct effect, but determined species diversity and richness. Third, stand structure seemed to 
have the largest direct influence on bird assembly structure in most forest stands. Oak and pine stands harboured different set-ups of bird assemblages and hence differed in their capacities to support suitable habitats for some birds. Furthermore, oak stands supported higher bird species richness and diversity, and a higher proportion of unique species. As the number of bird territories and the total metabolic weight of bird assemblages did not differ between stands of oak and pine, it is suggested that there are no differences in the availability of total food resources. Although stand age and stand structure were found to be the most important variables determining bird assembly structure, the abundance of some species and functional groups were more likely to be explained by forest type. At the level of guilds, ground-nesters and primary cavity-nesters were significantly more abundant in oak stands, indicating that pine stands lack some features vital in supporting species belonging to these guilds. When analyzing only the pine stands sampled, the strongest association was found between ground-nesters and the amount of grass and herbaceous vegetation in the forest understory. Since understory vegetation is scarce in most pine stands, this association suggests that these birds may be constrained by lack of suitable nest sites. For primary cavity-nesters the associations with stand structure in pine stands were less clear due to few observations. Due to most woodpeckers' high association with oak stands, structures important for nesting and foraging may be closely connected to the properties of the trees themselves, e.g. through existence of natural cavities and standing deadwood providing enough invertebrates to feed upon. If so, these species will be confined to oak stands and be unable to occupy pine stands. Replacing oak stands with pine plantations, a common measure in many parts of the Mediterranean basin, thus will cause an inevitable loss of highly oakassociated species and result in habitats supporting a lower species richness of forest birds.

\section{Management implications}

Desirable aspects of sustainable forestry are to appropriately manage forests without losing forest biodiversity. This balance need to be thoroughly evaluated to identify how forestry management regimes can be improved to benefit breeding birds. The most important aspect for pine stands in the studied province is to strive for an increased amount of old trees, preferably by extending the rotation time or implementing tree retention (Gustavsson et al., 2010). Furthermore, a certain amount of understory cover of shrubs, low trees and vascular plants need to be retained to benefit birds associated with such attributes, and enhance overall species richness in managed pine stands. Given the considerable fire hazard (Özturk et al., 2010) a key challenge is to strike a balance with fire prevention activities which aims to reduce flammable biomass.

To secure future distribution of oak stands in the forest landscape of southwestern Turkey, alternatives to monospecific conifer plantation forestry need to be explored, including forestry practices using oak trees. Several stands, particularly those comprising old hollow trees, need protection. A sustainably focused forestry need to include also the conservation of old stands and the promotion of recruitment of new oak stands to secure oak continuity at a landscape scale. Extensive grazing may, if practiced over prolonged periods, constrain recruitment of new oaks in some areas, potentially threatening future oak continuity. More research is needed to evaluate the biological values associated with oak stands in southwestern Turkey.

\section{Acknowledgements}

We are grateful to the Turkish General Directorate of Forestry for letting us conduct research in their forests, and to the Forest Ministries in Isparta, Eğirdir, Sütçüler and Yalvaç for help and information. Adnan Güller, Sibel Korkmaz and Özlem Gafar provided useful logistic support, while Halis Bereket, Mehmet Çakir, Osman Mücahit Doğan, Kazım Kanlı, Ayhan Başpinar, Nevzat Akyüz, 
Cebrail Akaslan and İsmail Tuncer assisted in the field. The study was financially supported by ERASMUS and through a "Minor Field Studies" scholarship grant provided by the Swedish International Development Cooperation Agency (SIDA).

\section{References}

Archaux, F., Bakkaus, N., 2007. Relative impact of stand structure, tree composition and climate on mountain bird communities. Forest Ecol. Manage. 247, 72-79.

Atmiş, E., Özden, S., Lise, W., 2007. Urbanization pressures on the natural forests in Turkey: An overview. Urban For. Urban Greening 6, 83-92.

Banavar, J.R., Moses, M.E., Brown, J.H., Damuth, J., Rinaldo, A., Sibly, R.M., Maritan, A., 2010. A general basis for quarter-power scaling in animals. Proc. Natl Acad. Sci. USA 107, 1581615820 .

Barbaro, L., Pontcharraud, L., Vetillard, F., Guyon, D., Jactel, H., 2005. Comparative responses of bird, carabid, and spider assemblages to stand and landscape diversity in maritime pine plantations. EcoScience 12, 110-121.

Barbéro, M., Bonin, G., Loisel, R., Quézel, P., 1990. Changes and disturbances of forest ecosystems caused by human activities in the western part of the Mediterranean basin. Vegetatio 87, 151173.

Başkent, E.Z., Terzioğlu, S., Başkaya, Ş., 2008. Developing and implementing multiple-use forest management planning in Turkey. Environ. Manage. 42, 37-48.

Bergmeier, E., Petermann, J., Schröder, E., 2010. Geobotanical survey of wood-pasture habitats in Europe: diversity, threats and conservation. Biodiversity Conserv. 19, 2995-3014.

Bibby, C.J., Burgess, N.D., Hill, D.A., 2000. Bird census techniques, second edition. Academic Press, London.

Blondel, J., Aronson, J., 1999. Biology and wildlife of the Mediterranean region. Oxford University Press.

Blondel, J., Farré, H., 1988. The convergent trajectories of bird communities along ecological successions in European forests. Oecologia 75, 83-93.

Boulinier, T., Nichols, J.D., Sauer, J.R., Hines, J.E., Pollock, K.H., 1998. Estimating species richness: the importance of heterogeneity in species detectability. Ecology 79, 1018-1028.

Camprodon, J., Brotons, L., 2006. Effects of undergrowth clearing on the bird communities of the Northwestern Mediterranean Coppice Holm oak forests. Forest Ecol. Manage. 221, 72-82.

Ciancio, O., Corona, P., Lamonaca, A., Portoghesi, L., Travaglini, D., 2006. Conversion of clear-cut beech coppices into high forests with continuous cover: a case study in central Italy. Forest Ecol. Manage. 224, 235-240.

Ciudad, C., Robles, H., Matthysen, E., 2009. Postfledging habitat selection of juvenile middle spotted woodpeckers: a multi-scale approach. Ecography 32, 676-682.

Cockle, K.L., Martin, K., Wesolowski, T., 2011. Woodpeckers, decay, and the future of cavity-nesting vertebrate communities worldwide. Frontiers Ecol. Environ. 9, 377-382. 
Çolak, A.H., Rotherham, I.D., 2006. A review of the forest vegetation of Turkey: its status past and present and its future conservation. Proc. R. Irish Acad. B 106, 343-354.

Cramp, S. (Ed.), 1985. The birds of the Western Palearctic. Volume 4. Oxford University Press.

Cramp, S. (Ed.), 1988. The birds of the Western Palearctic. Volume 5. Oxford University Press.

Cramp, S., Brooks, D.J. (Ed.), 1992. The birds of the Western Palearctic. Volume 6. Oxford University Press.

Cramp, S., Perrins, C.M., Brooks, D.J. (Ed.), 1993. The birds of the Western Palearctic. Volume 7. Oxford University Press.

Cramp, S., Perrins, C.M. (Ed.), 1994a. The birds of the Western Palearctic. Volume 8. Oxford University Press.

Cramp, S., Perrins, C.M. (Ed.), 1994b. The birds of the Western Palearctic. Volume 9. Oxford University Press.

Cramp, S., Simmons, K.E.L. (Ed.), 1980. The birds of the Western Palearctic. Volume 2. Oxford University Press.

Debussche, M., Debussche, G., Lepart, J., 2001. Changes in the vegetation of Quercus pubescens woodland after cessation of coppicing and grazing. J. Veg. Sci. 12, 81-92.

Díaz, L., 2006. Influences of forest type and forest structure on bird communities in oak and pine woodlands in Spain. Forest Ecol. Manage. 223, 54-65.

Díaz, M., Carbonell, R., Santos, T., Tellería, J.L., 1998. Breeding bird communities in pine plantations of the Spanish plateaux: biogeography, landscape and vegetation effects. J. Appl. Ecol. 35, 562574.

Donald, P.F., Fuller, R.J., Evans, A.D., Gough, S.J., 1998. Effects of forest management and grazing on breeding bird communities in plantations of broadleaved and coniferous trees in western England. Biol. Conserv. 85, 183-197.

Enoksson, B., Angelstam, P., Larsson, K., 1995. Deciduous forest and resident birds: the problem of fragmentation within a coniferous forest landscape. Landscape Ecol. 10, 267-275.

Etterson, M.A., Etterson, J.R., Cuthbert, F.J., 2007. A robust new method for analyzing community change and an example using 83 years of avian response to forest succession. Biol. Conserv. $138,381-389$.

Fabbio, G., Merlo, M., Tosi, V., 2003. Silvicultural management in maintaining biodiversity and resistance of forests in Europe - the Mediterranean region. J. Env. Manage. 67, 67-76.

FAO., 2013. State of Mediterranean forests 2013. Report. 177 pp.

Gil-Tena, A., Brotons, L., Saura, S., 2009. Mediterranean forest dynamics and forest bird distribution changes in the late 20th century. Global Change Biol. 15, 474-485.

Gil-Tena, A., Saura, S., Brotons, L., 2007. Effects of forest composition and structure on bird species richness in a Mediterranean context: implications for forest ecosystem management. Forest Ecol. Manage. 242, 470-476.

Gündoğdu, E., Türkay, O.Ç., Ertuğrul, E.T., 2009. Isparta'nin Kuşlari. TC Isparta Valiliği, Isparta. 
Gustafsson, L., Kouki, J., Sverdrup-Thygeson, A., 2010. Tree retention as a conservation measure in clear-cut forests of northern Europe: a review of ecological consequences. Scand. J. For. Res. $25,295-308$.

Hartel, T., Hanspach, J., Abson, D.J., Máthé, O., Moga, C.I., Fischer, J., 2014. Bird communities in traditional wood-pastures with changing management in Eastern Europe. Basic Appl. Ecol. 15, 385-395.

Hartley, M.J., 2002. Rationale and methods for conserving biodiversity in plantation forests. Forest Ecol. Manage. 155, 81-95.

Hatchwell, B.J., Anderson, C., Ross, D.J., Fowlie, M.K., Blackwell, P.G., 2001. Social organization of cooperatively breeding long-tailed tits: kinship and spatial dynamics. J. Anim. Ecol. 70, 820 830 .

Heyman, E., 2010. Clearance of understory in urban woodlands: assessing impact on bird abundance and diversity. Forest Ecol. Manage. 260, 125-131.

Hingston, A.B., Grove, S., 2010. From clearfell coupe to old-growth forest: succession of bird assemblages in Tasmanian lowland wet eucalypt forests. Forest Ecol. Manage. 259, 459-468.

Horak, J., Vodka, S., Kout, J., Halda, J.P., Bogusch, P., Pech, P., 2014. Biodiversity of most dead wood-dependent organisms in thermophilic temperate oak woodlands thrives on diversity of open landscape structures. Forest Ecol. Manage. 315, 80-85.

Kaya, Z., Raynal, D.J., 2001. Biodiversity and conservation of Turkish forests. Biol. Conserv. 97, $131-141$.

Kennedy, C.E.J., Southwood, T.R.E., 1984. The number of species of insects associated with British trees: a re-analysis. J. Anim. Ecol. 53, 455-478.

Lindenmayer, D.B., Hobbs, R.J., 2004. Fauna conservation in Australian plantation forests - a review. Biol. Conserv. 119, 151-168.

Lindenmayer, D.B., Margules, C.R., Botkin, D.B., 2000. Indicators of biodiversity for ecologically sustainable forest management. Conserv. Biol. 14, 941-950.

Lopez, G., Moro, M.J., 1997. Birds of Aleppo pine plantations in south-east Spain in relation to vegetation composition and structure. J. Appl. Ecol. 34, 1257-1272.

Luck, G.W., Korodaj, T.N., 2008. Stand and landscape-level factors related to bird assemblages in exotic pine plantations: implications for forest management. Forest Ecol. Manage. 255, 2688 2697.

Maestre, F.T., Cortina, J., 2004. Are Pinus halepensis plantations useful as a restoration tool in semiarid Mediterranean areas? Forest Ecol. Manage. 198, 303-317.

Marques, T.A., Thomas, L., Fancy, S.G., Buckland, S.T., 2007. Improving estimates of bird density using multiple-covariate distance sampling. The Auk 124, 1229-1243.

Martin, K., Eadie, J.M., 1999. Nest webs: a community-wide approach to the management and conservation of cavity-nesting forest birds. Forest Ecol. Manage. 115, 243-257.

Mikusiński, G., Gromadzki, M., Chylarecki, P., 2001. Woodpeckers as indicators of forest bird diversity. Conserv. Biol. 15, 208-217.

Newton, I., 1998. Population limitation in birds. Academic Press, London. 
Nikolov, S.C., 2009. Effect of stand age on bird communities in late-successional Macedonian pine forests in Bulgaria. Forest Ecol. Manage. 257, 580-587.

Özkan, K., Svenning, J-C., Jeppesen, E., 2013. Environmental species-sorting dominates forest-bird community assembly across scales. J. Anim. Ecol. 82, 266-274.

Öztürk, M., Gücel, S., Kücük, M., Sakcali, S., 2010. Forest diversity, climate change and forest fires in the Mediterranean region of Turkey. J. Envir. Biol. 31, 1-9.

Pasinelli, G., 2000. Oaks (Quercus sp.) and only oaks? Relations between habitat structure and home range size of the middle spotted woodpecker (Dendrocopos medius). Biol. Conserv. 93, 227235.

Pausas, J.G., Bladé, C., Valdecantos, A., Seva, J.P., Fuentes, D., Alloza, J.A., Vilagrosa, A., Bautista, S., Cortina, J., Vallejo, R., 2004. Pines and oaks in the restoration of Mediterranean landscapes of Spain: new perspectives for an old practice - a review. Plant Ecol. 171, 209-220.

Pereira, P., Godinho, C., Roque, I., Marques, A., Branco, M., Rabaça, J.E., 2014. Time to rethink the management intensity in a Mediterranean oak woodland: the response of insectivorous birds and leaf-chewing defoliators as key groups in the forest ecosystem. Ann. For. Sci. 71, 25-32.

Regnery, B., Paillet, Y., Couvet, D., Kerbiriou, C., 2013. Which factors influence the occurrence and density of tree microhabitats in Mediterranean oak forests? Forest Ecol. Manage. 295, 118-125.

Roberge, J. M., Angelstam, P., 2006. Indicator species among resident forest birds-a cross-regional evaluation in northern Europe. Biol. Conserv. 130, 134-147.

Robles, H., Ciudad, C., 2012. Influence of habitat quality, population size, patch size, and connectivity on patch-occupancy dynamics of the Middle Spotted Woodpecker. Conserv. Biol. 26, 284-293.

Robles, H., Ciudad, C., Vera, R., Olea, P.P., Purroy, F.J., Matthysen, E., 2007. Sylvopastoral management and conservation of the middle spotted woodpecker at the south-western edge of its distribution range. Forest Ecol. Manage. 242, 343-352.

Robles, H., Ciudad, C., Matthysen, E., 2011. Tree-cavity occurrence, cavity occupation and reproductive performance of secondary cavity-nesting birds in oak forests: the role of traditional management practices. Forest Ecol. Manage. 261, 1428-1435.

Robles, H., Ciudad, C., Matthysen, E., 2012. Responses to experimental reduction and increase of cavities by a secondary cavity-nesting bird community in cavity-rich Pyrenean oak forests. Forest Ecol. Manage. 277, 46-53.

Sama, G., Jansson, N., Avc1, M., Sarikaya, O., Coşkun, M., Kayiş, T., Özdikmen, H., 2011. Preliminary report on a survey of the saproxylic beetle fauna living on old hollow oaks (Quercus spp.) and oak wood in Turkey (Coleoptera: Cerambycidae). Munis Entomol. Zool. 6, 819-831.

Santos, T., Tellería, J.L., Carbonell, R., 2002. Bird conservation in fragmented Mediterranean forests of Spain: effects of geographical location, habitat and landscape degradation. Biol. Conserv. $105,113-125$.

Scarascia-Mugnozza, G., Oswald, H., Piussi, P., Radoglou, K., 2000. Forests in the Mediterranean region: gaps in knowledge and research needs. Forest Ecol. Manage. 132, 97-109.

Schieck, J., 1997. Biased detection of bird vocalizations affects comparisons of bird abundance among forested habitats. The Condor 99, 179-190. 
Şekercioğlu, Ç.H., 2006. Increasing awareness of avian ecological function. Trends Ecol. Evol. 21, 464-471.

Spitzer, L., Konvicka, M., Benes, J., Tropek, R., Tuf, I.H., Tufova, J., 2008. Does closure of traditionally managed open woodlands threaten epigeic invertebrates? Effects of coppicing and high deer densities. Biol. Conserv. 141, 827-837.

Stephens, S.S., Wagner, M.R., 2007. Forest plantations and biodiversity: a fresh perspective. J. For. $105,307-313$.

Svensson, L., Mullarney, K., Zetterström, D., 2009 Fågelguiden - Europas och Medelhavsområdets fåglar i fält. Andra omarbetade och utökade upplagan. Bonnier Fakta.

Sweeney, O.F.M.D., Wilson, M.W., Irwin, S., Kelly, T.C., O’Halloran, J., 2010a. Are bird density, species richness and community structure similar between native woodlands and non-native plantations in an area with a generalist bird fauna? Biodivers. Conserv. 19, 2329-2342.

Sweeney, O.F.M.D., Wilson, M.W., Irwin, S., Kelly, T.C., O'Halloran, J., 2010b. Breeding bird communities of second-rotation plantations at different stages of the forest cycle. Bird Study 57, 301-314.

Tellería, J.L., Carrascal, L.M., 1994. Weight-density relationships between and within bird communities: implications of niche space and vegetation structure. Am. Nat. 143, 1083-1092.

Tellería, J.L., Santos, T., Sánchez, A., Galarza, A., 1992. Habitat structure predicts bird diversity distribution in Iberian forests better than climate. Bird Study 39, 63-68.

ter Braak, C.J.F., Šmilauer, P., 2012. Canoco reference manual and user's guide: software for ordination, version 5.0. Microcomputer Power, Ithaca, USA. 496 pp.

Tews, J., Brose, U., Grimm, V., Tielbörger, K., Wichmann, M.C., Schwager, M., Jeltsch, F., 2004. Animal species diversity driven by habitat heterogeneity/diversity: the importance of keystone structures. J. Biogeogr. 31, 79-92.

Thirgood, J.V., 1981. Man and the Mediterranean forest - a history of resource depletion. Academic Press, London.

Thomas, L., Buckland, S.T., Burnham, K.P., Anderson, D.R., Laake, J.L., Borchers, D.L., Strindberg, S., 2002. Distance sampling. Encyclopedia of Environmetrics 1, 544-552.

Thomas, L., Buckland, S.T., Rexstad, E.A., Laake, J.L., Strindberg, S., Hedley, S.L., Bishop, J.R.B., Marques, T.A., Burnham, K.P., 2010. Distance software: design and analysis of distance sampling surveys for estimating population size. J. Appl. Ecol. 47, 5-14.

Touihri, M., Villard, M. A., Charfi, F., 2014. Cavity-nesting birds show threshold responses to stand structure in native oak forests of northwestern Tunisia. For. Ecol. Manage. 325, 1-7.

Van Dorp, D., Opdam, P.F.M., 1987. Effects of patch size, isolation and regional abundance on forest bird communities. Landscape Ecol. 1, 59-73.

Venier, L.A., Pearce, J.L., 2005. Boreal bird community response to jack pine forest succession. Forest Ecol. Manage. 217, 19-36.

Wilson, M.W., Pithon, J., Gittings, T., Kelly, T.C., Giller, P.S., O'Halloran, J., 2006. Effects of growth stage and tree species composition on breeding bird assemblages of plantation forests. Bird Study 53, 225-236. 


\section{Figure legends}

Figure 1. The study area in the province of Isparta, southwestern Anatolia, Turkey.

Figure 2. Association between bird species richness and stand age in oak stands (solid line) and pine stands (dashed line). The two lines based on results from a GLZ: $\mathrm{y}_{\text {oak }}=0.044 * x+9.10$; $\mathrm{y}_{\text {pine }}=0.044 * \mathrm{x}+6.34$.

Figure 3. The effect of forest type on total number of territories of birds grouped according to guilds that reflect nest-site preference. Effect sizes (with $\mathrm{CI}_{95 \%}$ ) are slope parameters as calculated in GLZ for responses of bird guilds to forest type and adjusted for effects of one each of four different attributes of stand structure (listed to the left).

Figure 4. The effect of stand age on total number of territories of birds grouped according to guilds that reflect nest-site preference. Effect sizes (with $\mathrm{CI}_{95 \%}$ ) are slope parameters as calculated in GLZ for responses of bird guilds to stand age and adjusted for effects of forest type. The X-axis indicates the associations with stand age, ranging from young to old.

Figure 5. a) RDA based on species-wise bird territory data for oak and pine stands; a) the 20 bird species showing the strongest responses to included habitat variables. b) the explanatory habitat variables (bold); guild abundance data added as passive variables. The first axis explained $12.3 \%$ and the second axis $9.0 \%$ of the observed variation in bird assembly data.

Figure 6. RDA based on species-wise bird territory data for pine stands only, showing the explanatory habitat variables (bold); guild abundance data added as passive variables. The first axis explained $20 \%$ and the second axis $8.4 \%$ of the total variation in bird assembly data. 
Table 1. The 40 bird species registered in the study per forest type and their classification in nestingguilds (HCN: high-canopy nesters; LCN: low-canopy nesters; PCN: primary cavity-nesters; SCN: secondary cavity-nesters; SN: shrub-nesters; GN: ground-nesters). Nomenclature follows Svensson et al. (2009).

\begin{tabular}{|c|c|c|c|c|c|}
\hline \multirow{3}{*}{ Nesting guild } & \multirow[b]{3}{*}{ Nest site } & \\
\hline & & \multirow[b]{2}{*}{ Species } & \multirow[b]{2}{*}{ Scientific name } & \multicolumn{2}{|c|}{ Presence/absence } \\
\hline & & & & Pinus & Quercus \\
\hline \multirow[t]{6}{*}{$\begin{array}{l}\text { High canopy- } \\
\text { nesters }\end{array}$} & $\begin{array}{l}\text { Branches of higher } \\
\text { trees }\end{array}$ & & & & \\
\hline & & Eurasian Sparrowhawk & Accipiter nisus & $x$ & \\
\hline & & Common Wood Pigeon & Columba palumbus & $x$ & \\
\hline & & Mistle Thrush & Turdus viscivorus & $x$ & $x$ \\
\hline & & Golden Oriole & Oriolus oriolus & $x$ & $x$ \\
\hline & & European Goldfinch & Carduelis carduelis & $x$ & $x$ \\
\hline \multirow[t]{12}{*}{ Low canopy-nesters } & $\begin{array}{l}\text { Branches of high } \\
\text { shrubs or lower trees }\end{array}$ & & & & \\
\hline & & Eurasian Collared Dove & $\begin{array}{l}\text { Streptopelia } \\
\text { decaocto }\end{array}$ & $x$ & \\
\hline & & Turtle Dove & Streptopelia turtur & $x$ & $x$ \\
\hline & & Common Blackbird & Turdus merula & $\mathrm{X}$ & $x$ \\
\hline & & $\begin{array}{l}\text { Lesser Whitethroat } \\
\text { Eastern Orphean } \\
\text { Warbler }\end{array}$ & $\begin{array}{l}\text { Sylvia curruca } \\
\text { Sylvia crassirostris }\end{array}$ & $x$ & $\begin{array}{l}x \\
x\end{array}$ \\
\hline & & $\begin{array}{l}\text { Olive-tree Warbler } \\
\text { Eastern Olivaceous } \\
\text { Warbler }\end{array}$ & $\begin{array}{l}\text { Hippolais olivetorum } \\
\text { Iduna pallida }\end{array}$ & & $\begin{array}{l}x \\
x\end{array}$ \\
\hline & & Long-tailed Tit & Aegithalos caudatus & $x$ & $x$ \\
\hline & & Masked Shrike & Lanius nubicus & & $x$ \\
\hline & & Eurasian Jay & Garrulus glandarius & $\mathrm{X}$ & $X$ \\
\hline & & Common Chaffinch & Fringilla coelebs & $x$ & $x$ \\
\hline & & European Greenfinch & Chloris chloris & $\mathrm{X}$ & $x$ \\
\hline & & Serin & Serinus serinus & $\mathrm{X}$ & $x$ \\
\hline \multirow[t]{3}{*}{ Shrub-nesters } & $\begin{array}{l}\text { In shrubs, often } \\
\text { thorny ones }\end{array}$ & & & & \\
\hline & & Sardinian Warbler & $\begin{array}{l}\text { Sylvia } \\
\text { melanocephala }\end{array}$ & $x$ & \\
\hline & & Rüppell's Warbler & Sylvia rueppelli & $x$ & $x$ \\
\hline \multirow{6}{*}{ Ground-nesters } & $\begin{array}{l}\text { On the ground, often } \\
\text { in dense grass tussoc }\end{array}$ & & & & \\
\hline & or near shrubs & & Luscinia & & \\
\hline & & $\begin{array}{l}\text { Common Nightingale } \\
\text { Eastern Bonelli's }\end{array}$ & $\begin{array}{l}\text { megarhynchos } \\
\text { Phylloscopus }\end{array}$ & & $x$ \\
\hline & & Warbler & $\begin{array}{l}\text { orientalis } \\
\text { Phylloscopus }\end{array}$ & $X$ & $X$ \\
\hline & & Chiffchaff & collybita & $x$ & \\
\hline & & Ortolan Bunting & Emberiza hortulana & $x$ & $x$ \\
\hline \multirow[t]{2}{*}{$\begin{array}{l}\text { Primary cavity- } \\
\text { nesters }\end{array}$} & $\begin{array}{l}\text { Tree cavities created } \\
\text { by themselves }\end{array}$ & & & & \\
\hline & & European Green & Picus viridis & & $x$ \\
\hline
\end{tabular}


Woodpecker

Greater Spotted

Woodpecker

Dendrocopus major $\quad \mathrm{X} \quad \mathrm{X}$

Syrian Woodpecker

Middle Spotted

Dendrocopus

syriacus

$x \quad x$

Woodpecker

Dendrocopus

medius

$X$

Dendrocopus minor

$X$

Natural cavities or

Secondary cavity-

tree cavities created

nesters

by other species

European Robin
Common Redstart
Eurasian Wren
Spotted Flycatcher
Great Tit
Coal Tit
Blue Tit
Eurasian Nuthatch
Krüper's Nuthatch
Short-toed Treecreeper
Eurasian Tree Sparrow

Erithacus rubecula

$\mathrm{X}$

Phoenicurus

phoenicurus

Troglodytes

troglodytes

Muscicapa striata

Parus major

Periparus ater

Cyanistes caeruleus

Sitta europaea

Sitta krueperi

Certhia

brachydactyla

Passer montanus

$x$
$x$
$x$
$x$
$x$
$x$
$x$
$x$
$x$
$x$
$x$


Table 2. Environmental variables for stands of pine $(n=17)$ and oak $(n=15)$.

\begin{tabular}{|c|c|c|c|c|c|c|c|c|}
\hline & Pine & & & Oak & & & & \\
\hline Variables & Mean & $\pm \mathrm{Cl} 95 \%$ & Range & Mean & $\pm \mathrm{Cl} 195 \%$ & Range & Test & P-value \\
\hline Tree trunk density $\left(\mathrm{N} / 100 \mathrm{~m}^{2}\right)$ & 5.72 & 1.6 & $1.75-12.5$ & 6.3 & 1.42 & $1.0-12.5$ & $t=0.524$ & 0.604 \\
\hline Tree trunk circumference $(\mathrm{cm})$ & 108.2 & 26.4 & $32.4-216.4$ & 68.3 & 9.96 & $23.0-156.9$ & $\mathrm{t}=-2.31$ & 0.028 \\
\hline Stand age (yrs) & 61.8 & 20.2 & $15-148$ & 75 & 19.8 & 23-185 & $U=97.0$ & 0.261 \\
\hline Shrub cover (\%) & 27.2 & 7.25 & $2.0-62.1$ & 31.5 & 10.9 & $4.5-66.1$ & $\mathrm{t}=0.653$ & 0.519 \\
\hline Grass and herbs cover (\%) & 7.31 & 3.63 & $0.13-19.6$ & 23.7 & 9.18 & $3.1-48.6$ & $U=46.0$ & 0.002 \\
\hline Altitude (m.a.s.) & 1082 & 80.1 & $856-1376$ & 1206 & 86.7 & $1004-1524$ & $t=2.06$ & 0.046 \\
\hline
\end{tabular}

Table 3. Total species richness, species diversity (Shannon-Wiener index), territory density and metabolic weight of bird assemblages in stands of pine and oak in SW Turkey.

\begin{tabular}{lcccccc} 
& Pine & \multicolumn{5}{c}{ Oak } \\
Variable & Mean & CI95\% & Mean & Cl95\% & Test & P-value \\
Species richness (N) & 9.06 & $7.70-10.40$ & 12.4 & $10.8-13.9$ & $\mathrm{t}=3.188$ & 0.003 \\
Shannon-Wiener (H') & 1.86 & $1.72-2.00$ & 2.17 & $2.06-2.28$ & $\mathrm{t}=3.398$ & 0.002 \\
Territory density (N/ha) & 19.9 & $16.0-23.9$ & 23.6 & $19.2-27.9$ & $\mathrm{t}=1.207$ & 0.237 \\
Metabolic weight (g/ha) & 463 & $391-534$ & 492 & $407-577$ & $\mathrm{t}=0.524$ & 0.604
\end{tabular}




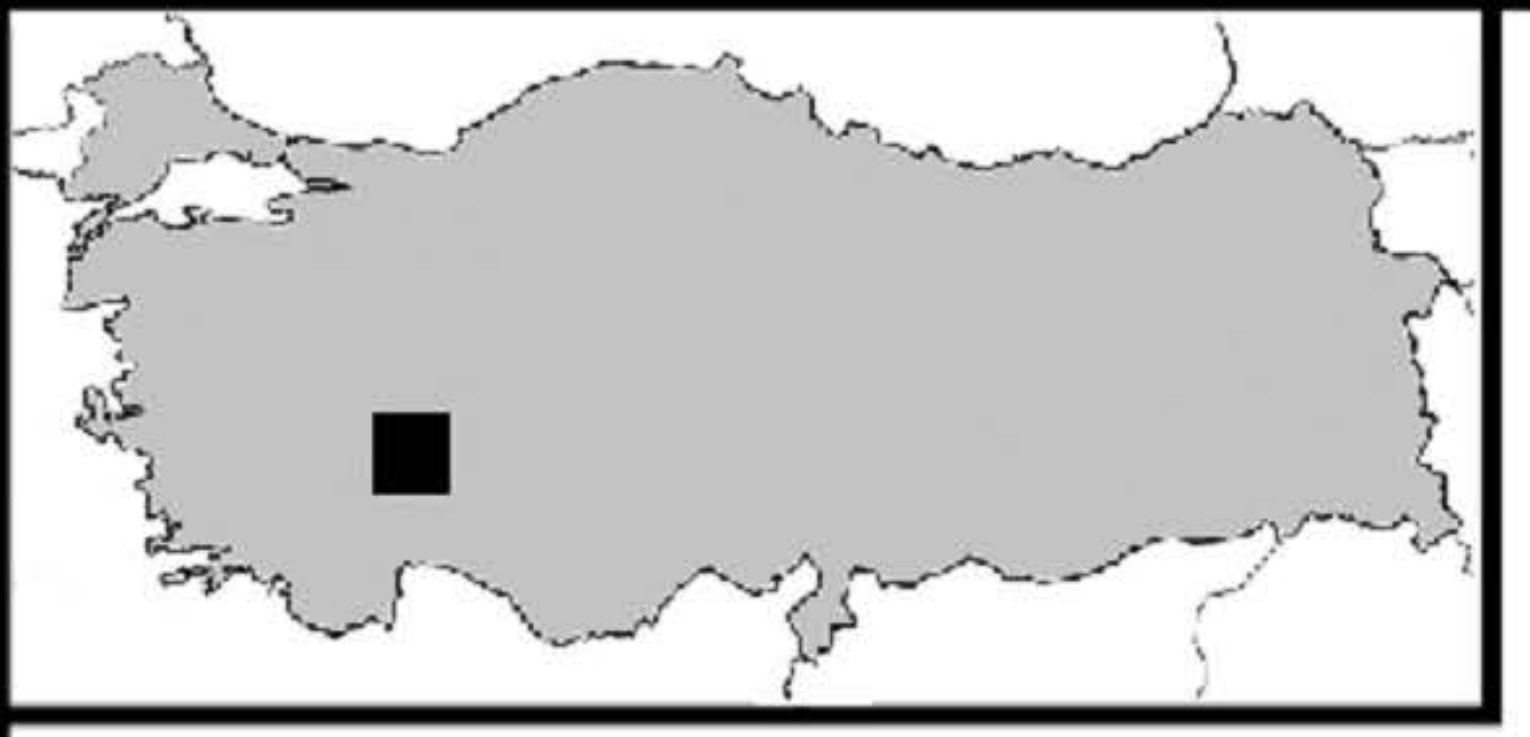

$+$

0

O

0

Isparta

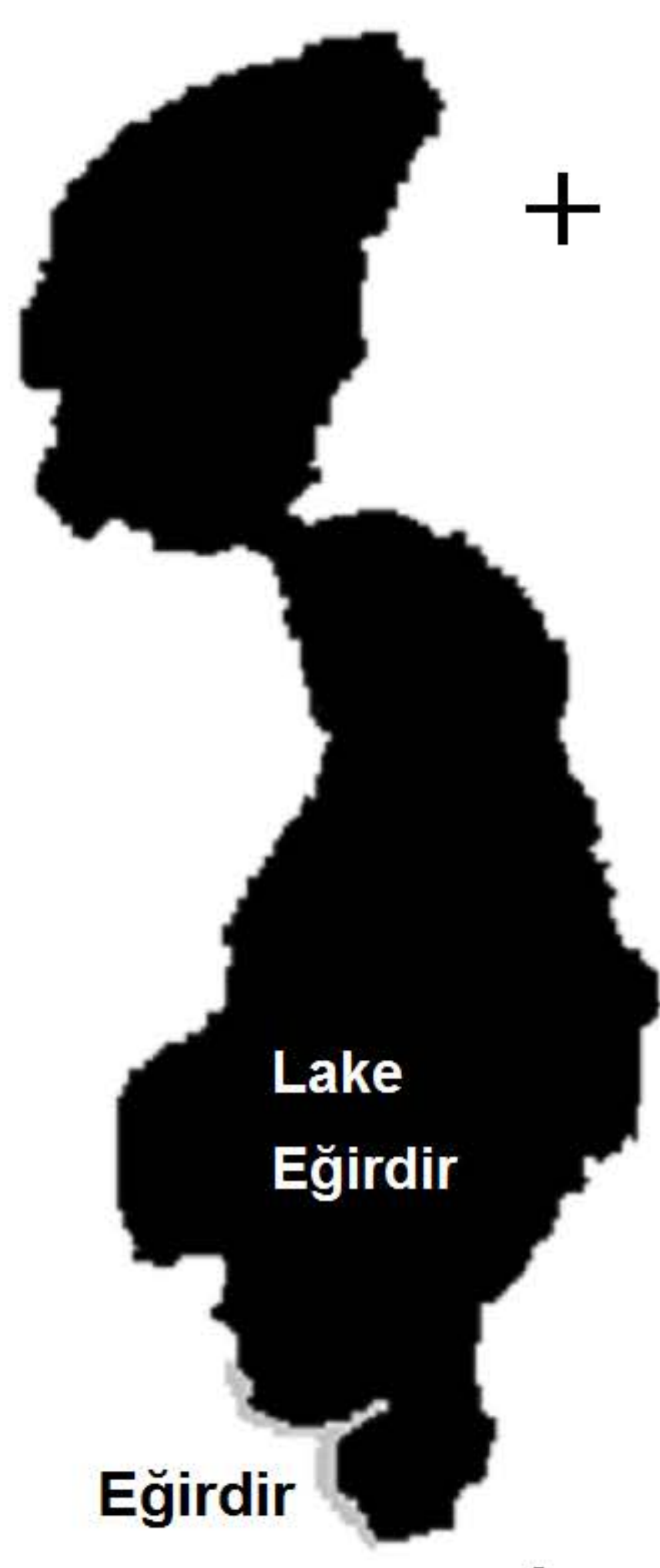

Yalvaç

$+$

$+$

0

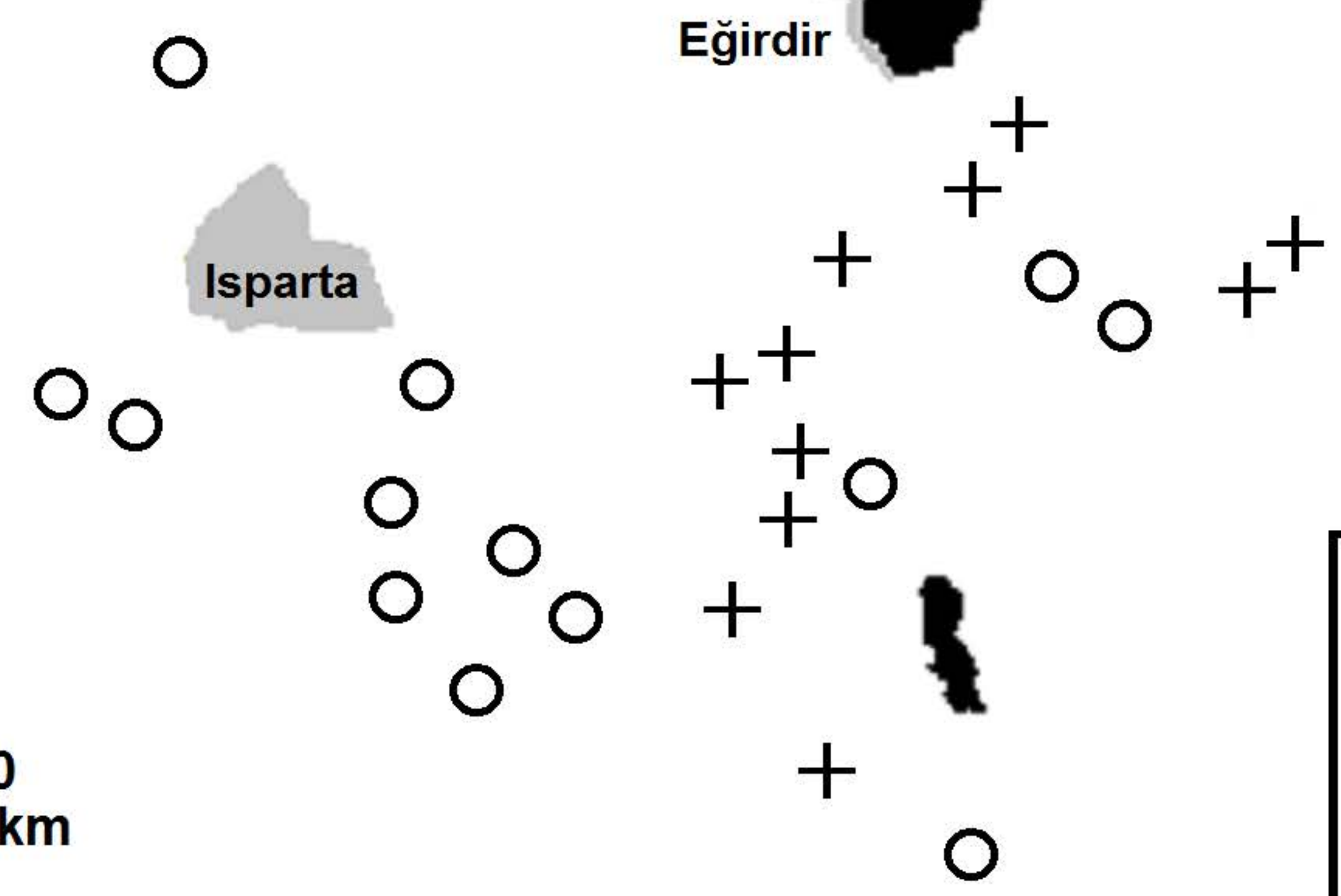

LEGEND

+ Oak

O Pine 


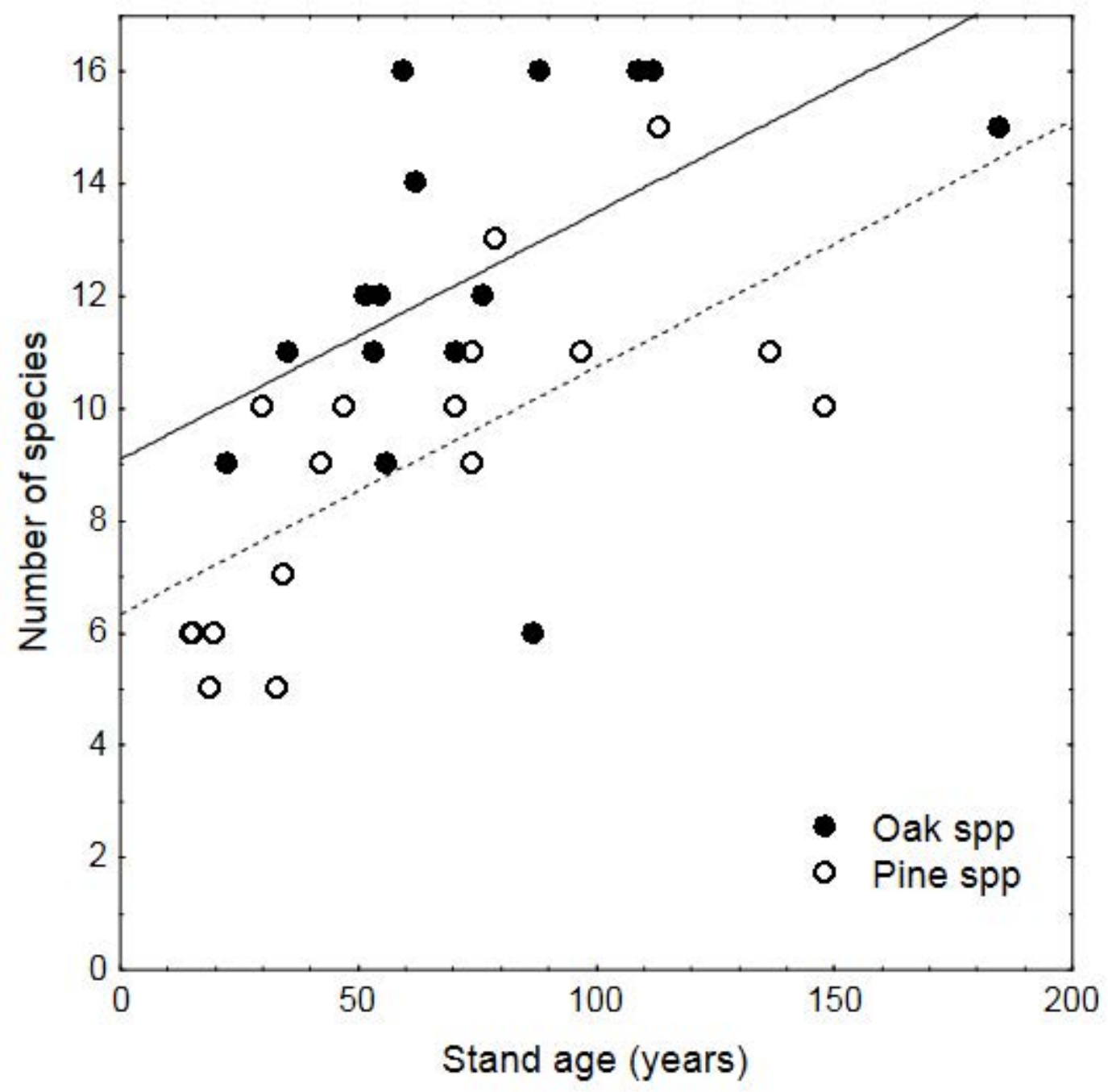
















